\title{
Deinococcus mumbaiensis Shashidhar and Bandekar 2006 is a later heterotypic synonym of Deinococcus ficus Lai et al. 2006
}

\author{
Peter Kämpfer
}

Correspondence

Peter Kämpfer

peter.kaempfer@umwelt.uni-

giessen.de

\author{
Institut für Angewandte Mikrobiologie, Justus-Liebig-Universität Giessen, D-35392 Giessen, \\ Germany
}

\begin{abstract}
Deinococcus mumbaiensis DSM $17424^{\top}$ was compared with Deinococcus ficus CC-FR2-10 ${ }^{\top}$ to clarify the taxonomic relationship between the two species. 16S rRNA gene sequence comparisons demonstrated that these strains share $99.5 \%$ sequence similarity. Investigation of fatty acid patterns and substrate utilization profiles displayed no striking differences between the type strains of the two species. DNA-DNA hybridizations between the two strains showed $75.4 \%$ $(76.6 \%)$ relatedness. Therefore, the reclassification of Deinococcus mumbaiensis as a later heterotypic synonym of Deinococcus ficus is proposed, based upon the estimated phylogenetic position derived from $16 \mathrm{~S}$ rRNA gene sequence data, fatty acid and biochemical data and DNADNA hybridization results.
\end{abstract}

Deinococcus mumbaiensis was proposed by Shashidhar \& Bandekar (2006a) for a radiation-resistant, pleomorphic bacterium isolated from Mumbai, India. The name was validly published in May 2006 (Shashidhar \& Bandekar, 2006b). Deinococcus ficus was described in April 2006 by Lai et al. (2006) for a pale-pink-pigmented bacterium isolated from the rhizosphere of Ficus religiosa L.

The two species were described at nearly the same time in different journals. Soon after the publication of the two studies, it became obvious that these species were closely related on the basis of $16 \mathrm{~S}$ rRNA gene sequence similarity. 16S rRNA gene sequences of Deinococcus mumbaiensis CON-1 ${ }^{\mathrm{T}}$ (GenBank accession no. DQ003135) and Deinococcus ficus CC-FR2-10 ${ }^{\mathrm{T}}$ (AY941086) shared a similarity of $99.5 \%$. A further comparative phenotypic analysis supported this finding. Fatty acid methyl esters were prepared, separated and identified according to the instructions of Microbial Identification System (MIDI; Microbial ID) (Kämpfer \& Kroppenstedt, 1996). The fatty acid profiles of the two strains are shown in Table 1. The difference in the content of iso- $\mathrm{C}_{17: 1} \omega 9 c$, which might be considered to be significant, is in fact within a range that has also been detected for other fatty acids in strains of Deinococcus species (Rainey et al., 2005; Lai et al. 2006).

Physiological/biochemical tests were performed with methods described previously (Kämpfer et al., 1991). The two strains shared the following biochemical characteristics. Aesculin, $p$-nitrophenyl (pNP) $\alpha$-D-glucopyranoside, pNP $\beta$-D-glucopyranoside, bis-pNP phosphate, bis-pNP

Abbreviations: pNA, p-nitroanilide; pNP, p-nitrophenyl. phenylphosphonate and bis-pNP phosphorylcholine are hydrolysed on the basis of the method described by Kämpfer et al. (1991). The following compounds are not hydrolysed: pNP $\beta$-D-galactopyranoside, $\mathrm{pNP} \beta$-D-glucuronide, pNP $\beta$-D-xylopyranoside, L-alanine $p$-nitroanilide (pNA), L-proline pNA and $\gamma$-L-glutamate pNA. D-Fructose, D-ribose and L-alanine are used as sole sources of carbon. The following compounds were not utilized: $N$-acetylgalactosamine, L-arabinose, L-arbutin, D-galactose, sucrose, D-xylose, D-mannitol, D-sorbitol, citrate, fumarate, glutarate, DL-3hydroxybutyrate, DL-lactate, L-malate, 2-oxoglutarate, pyruvate, L-proline, L-serine, D-gluconate, propionate, cis- and trans-aconitate, 4-aminobutyrate, itaconate, mesaconate, $\beta$ alanine, L-aspartate, L-leucine, L-ornithine, L-serine, $\mathrm{N}$ acetylglucosamine, cellobiose, D-mannose, $\alpha$-melibiose, Lrhamnose, salicin, trehalose, adonitol, myo-inositol, maltitol, putrescine, adipate, azelate, suberate, L-histidine, L-phenylalanine and L-tryptophan, on the basis of the method described by Kämpfer et al. (1991). Utilization of D-glucose and maltose became positive after incubation for 7 days for $D$. ficus CC-FR2- $10^{\mathrm{T}}$ and utilization of acetate became positive after incubation for 7 days for D. mumbaiensis DSM $17424^{\mathrm{T}}$.

DNA-DNA hybridization experiments were performed with strains $D$. ficus CC-FR2- $10^{\mathrm{T}}$ and $D$. mumbaiensis DSM $17424^{\mathrm{T}}$. DNA isolation and DNA-DNA hybridization were done as described previously (Ziemke et al., 1998). Results of the DNA-DNA cross-hybridization yielded a relatedness of $75.4 \%$, whereas reciprocal hybridization gave a higher value of $76.6 \%$.

Based on the presented results, it is proposed to unite the species Deinococcus mumbaiensis and Deinococcus ficus. 
Table 1. Cellular fatty acid contents of $D$. ficus CC-FR2-10 and D. mumbaiensis DSM $17424^{\top}$

Strains: 1, D. ficus CC-FR2-10 ${ }^{\mathrm{T}}$; 2, D. mumbaiensis DSM $17424^{\mathrm{T}}$. Values are percentages of total fatty acids. Minor fatty acids $(<0.5 \%)$ are not shown.

\begin{tabular}{|lrr|}
\hline Fatty acid & $\mathbf{1}$ & $\mathbf{2}$ \\
\hline iso- $_{15: 1} \mathrm{~F}$ & 1.0 & 1.7 \\
iso- $_{15: 0}$ & 3.7 & 4.8 \\
$\mathrm{C}_{15: 1} \omega 8 c$ & 4.0 & 2.3 \\
$\mathrm{C}_{15: 1} \omega 6 c$ & 6.6 & 4.3 \\
$\mathrm{C}_{15: 0}$ & 5.3 & 3.1 \\
$\mathrm{C}_{16: 1} \omega 9 c$ & 3.8 & 3.2 \\
Summed feature $3^{*}$ & 19.0 & 17.9 \\
$\mathrm{C}_{16: 0}$ & 8.0 & 7.3 \\
iso- $\mathrm{C}_{17: 1} \omega 9 c$ & 15.5 & 24.7 \\
iso- $\mathrm{C}_{17: 0}$ & 6.3 & 9.3 \\
$\mathrm{C}_{17: 1} \omega 8 c$ & 18.0 & 14.3 \\
$\mathrm{C}_{17: 1} \omega 6 c$ & 1.9 & 2.0 \\
$\mathrm{C}_{17: 0}$ & 4.1 & 3.3 \\
$\mathrm{C}_{18: 1} \omega 9 c$ & 0.8 & 1.0 \\
$\mathrm{C}_{18: 1} \omega 7 c$ & 0.6 & 0.9 \\
\hline
\end{tabular}

${ }^{\star}$ Summed feature 3 contains $\mathrm{C}_{16: 1} \omega 7 c$ and/or iso- $\mathrm{C}_{15: 0} 2-\mathrm{OH}$.

According to Rules 38, 42 and $24 \mathrm{~b}(2)$ of the Bacteriological Code (Lapage et al., 1992), the name Deinococcus ficus has priority and hence should be used for the unified taxon.

\section{Emended description of Deinococcus ficus Lai et al. 2006}

The characteristics of this species are as described by Lai et al. (2006), with the following amendment. Results of carbon substrate utilization depend heavily on the method. With the Biolog method, based on dehydrogenases (Lai et al., 2006), many more utilization tests (e.g. $N$-acetyl-Dglucosamine, L-arabinose, D-galactose, D-gluconic acid, Dmannitol, D-mannose, melibiose, methyl $\beta$-D-glucoside, raffinose, L-rhamnose, D-sorbitol, sucrose, trehalose, Dxylose, $\beta$-hydroxybutyric acid, $p$-hydroxyphenylacetic acid, L-lactic acid, D-malic acid, propionic acid, pyruvic acid, succinic acid and L-asparagine; Lai et al., 2006) are positive than with the growth-based method based on the increase of turbidity (see above). The type strain is CC-FR2-10 ${ }^{\mathrm{T}}$ $\left(=\right.$ CCUG $53391^{\mathrm{T}}=$ CIP $\left.108832^{\mathrm{T}}\right)$.

\section{References}

Kämpfer, P. \& Kroppenstedt, R. M. (1996). Numerical analysis of fatty acid patterns of coryneform bacteria and related taxa. Can J Microbiol 42, 989-1005.

Kämpfer, P., Steiof, M. \& Dott, W. (1991). Microbiological characterization of a fuel-oil contaminated site including numerical identification of heterotrophic water and soil bacteria. Microb Ecol 21, 227-251.

Lai, W. A., Kämpfer, P., Arun, A. B., Shen, F.-T., Huber, B., Rekha, P. D. \& Young, C. C. (2006). Deinococcus ficus sp. nov., isolated from the rhizosphere of Ficus religiosa L. Int J Syst Evol Microbiol 56, 787-791.

Lapage, S. P., Sneath, P. H. A., Lessel, E. F., Skerman, V. B. D., Seeliger, H. P. R. \& Clark, W. A. (editors) (1992). International Code of Nomenclature of Bacteria (1990 Revision). Bacteriological Code. Washington, DC: American Society for Microbiology.

Rainey, F. A., Ray, K., Ferreira, M., Gatz, B. Z., Nobre, M. F., Bagaley, D., Rash, B. A., Park, M. J., Earl, A. M. \& other authors (2005). Extensive diversity of ionizing-radiation-resistant bacteria recovered from Sonoran Desert soil and description of nine new species of the genus Deinococcus obtained from a single soil sample. Appl Environ Microbiol 71, 5225-5235.

Shashidhar, R. \& Bandekar, J. (2006a). Deinococcus mumbaiensis sp. nov., a radiation-resistant pleomorphic bacterium isolated from Mumbai, India. FEMS Microbiol Lett 254, 275-280.

Shashidhar, R. \& Bandekar, J. (2006b). Deinococcus mumbaiensis sp. nov. In List of New Names and New Combinations Previously Effectively, but not Validly, Published. Validation List no. 109. Int J Syst Evol Microbiol 56, 925-927.

Ziemke, F., Höfle, M. G., Lalucat, J. \& Rosselló-Mora, R. (1998). Reclassification of Shewanella putrefaciens Owen's genomic group II as Shewanella baltica sp. nov. Int J Syst Bacteriol 48, 179-186. 